\title{
The role of granulocyte colony-stimulating factor in breast cancer development: A review
}

\author{
LI LIU $^{1,2}$, YANGYANG LIU ${ }^{3}$, XIAOHUA YAN ${ }^{1}$, CHONG ZHOU $^{1}$ and XIANGYANG XIONG ${ }^{1}$ \\ ${ }^{1}$ Department of Biochemistry and Molecular Biology, School of Basic Medical Sciences, Nanchang University, Nanchang, \\ Jiangxi 330006; ${ }^{2}$ Central Laboratory, The First College of Clinical Medical Science, China Three Gorges University \\ and Yichang Central People's Hospital, Yichang, Hubei 443003; ${ }^{3}$ Department of Anesthesiology, First Clinical \\ Medical College, School of Medicine, Nanchang University, Nanchang, Jiangxi 330006, P.R. China
}

Received October 15, 2019; Accepted February 25, 2020

DOI: $10.3892 / \mathrm{mmr} .2020 .11017$

\begin{abstract}
Granulocyte-colony-stimulating factor (G-CSF) is a member of the hematopoietic growth factor family that primarily affects the neutrophil lineage. G-CSF serves as a powerful mobilizer of peripheral blood stem cells and recombinant human G-CSF (rhG-CSF) has been used to treat granulocytopenia and neutropenia after chemotherapy for cancer patients. However, recent studies have found that G-CSF plays an important role in cancer progression. G-CSF expression is increased in different types of cancer cells, such as lung cancer, gastric cancer, colorectal cancer, invasive bladder carcinoma, glioma and breast cancer. However, it is unclear whether treatment with G-CSF has an adverse effect. The current review provides an overview of G-CSF in malignant breast cancer development and the data presented in this review are expected to provide new ideas for cancer therapy.
\end{abstract}

\section{Contents}

1. Introduction

2. Structure of the G-CSF gene

3. Regulation of G-CSF gene expression

4. The G-CSF receptor

5. G-CSF expression in breast cancer

6. Direct effects of G-CSF on breast cancer

7. Role of tumor microenvironment in the effect of G-CSF on breast cancer

8. Conclusions

Correspondence to: Dr Xiangyang Xiong, Department of Biochemistry and Molecular Biology, School of Basic Medical Sciences, Nanchang University, 461 Bayi Avenue, Nanchang, Jiangxi 330006, P.R. China

E-mail: xiangyangxiong@ncu.edu.cn

Key words: Granulocyte-colony-stimulating factor, granulocytecolony-stimulating factor receptor, breast cancer, tumorigenesis, tumor microenvironment

\section{Introduction}

In the 1960s, two independent groups discovered several soluble factors when measuring mouse lymphoid leukemia cell growth $(1,2)$ and these soluble factors were named 'colony-stimulating factors' (CSFs). After isolation and purification, four CSFs were identified, including macrophage CSF (M-CSF, CSF1) (3), granulocyte-macrophage CSF (GM-CSF, CSF2) (4), granulocyte CSF (G-CSF, CSF3) (5) and multipotential CSF (also known as interleukin-3) (6). All these factors are essential stimulators of blood cell development and play a crucial role in hematopoietic stem cell proliferation and differentiation at different stages (7).

The biological effects of G-CSF are mediated by the specific G-CSF receptor (G-CSFR) (8). G-CSF is a critical regulator of neutrophil production and activity. It promotes proliferation and differentiation of the neutrophil lineage, and enhances the transition of immature metamyelocytes into mature neutrophils. G-CSF not only prolongs the survival of neutrophils and their precursors, but also promotes the functions of mature neutrophils, such as superoxide production, phagocytosis and pathogen killing (9).

G-CSF can act as a mobilizer of hematopoietic progenitor stem cells in blood donors or cancer patients (10). Therefore, recombinant human G-CSF (rhG-CSF) is commonly used to prevent and treat febrile neutropenia and mucositis after chemotherapy and radiotherapy for cancer patients (11). However, recent studies have found that G-CSF plays a crucial role in tumorigenesis. G-CSF promotes tumor growth, metastasis and chemotherapy resistance (12), inhibits tumor cell apoptosis, induces angiogenesis $(13,14)$, participates in cancer-associated thrombosis $(15,16)$, and is associated with a poor clinical prognosis (17).

\section{Structure of the G-CSF gene}

The human G-CSF gene is localized on chromosome 17q21-17q22 and spans $2.5 \mathrm{~kb}$ (18). As shown in Fig. 1, the $\mathrm{G}-\mathrm{CSF}$ gene consists of five exons and four introns. The promoter has $80 \%$ sequence similarity and the coding region shows $69 \%$ similarity between the human and murine G-CSF gene $(19,20)$. The TATA box is located -29 bp upstream of 


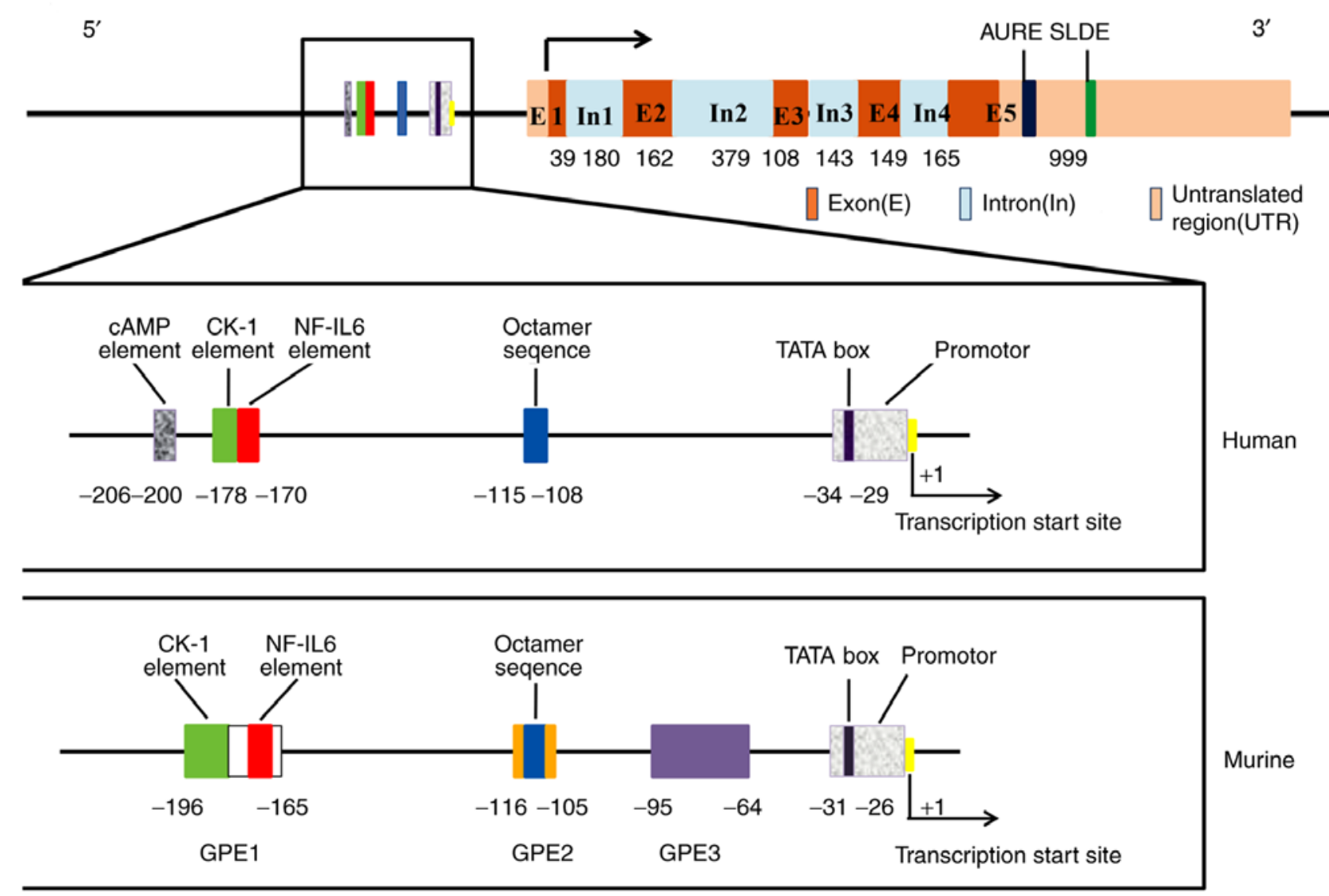

Figure 1. Structure of the G-CSF gene. The rectangular box below shows a detailed enlargement of the upstream transcriptional regulatory elements in the human and murine G-CSF gene promoter. The lengths of exons and introns are expressed in base pairs. G-CSF, granulocyte-colony stimulating factor; IL, interleukin; GPE, G-CSF promoter elements.

the transcription start site (21) and four specific regulatory elements have been identified within the promoter of the human G-CSF gene. Serving as the binding site of nuclear factor NF-GMa (20) and nuclear factor (NF)- $\mathrm{kB}(22,23)$, the CK-1 element (GAGATTCCA/CC) located 200 bp upstream of the transcription start site (24) is a highly conserved sequence that is found not only in the G-CSF gene but also in the GM-CSF and interleukin (IL)-3 genes (25). The NF-IL6 consensus element (ATTNNGNAAT) at a position ranging from -178 to -170 is the binding site of the transcription factor NF-IL6, which is involved in regulating the genes activated by lipopolysaccharide (LPS) (26).The octamer (OCT) sequence (ATTTGCAT) at -115 to -108 upstream of the transcription start site is the typical OCT transcription factor (OTF) binding site (27). Shannon et al (28), found that the above three elements in the G-CSF promoter are essential for tumor necrosis factor (TNF)- $\alpha$ and IL- $1 \beta$ responses. The cyclic AMP-responsive element at 11 bp upstream of CK-1 is the response element of cAMP-induced G-CSF gene transcription (29). A total of three regulatory regions within the murine G-CSF gene promoter known as G-CSF promoter elements (GPEs) 1-3 are required for G-CSF gene expression (30); of these three elements, CK-1 and NF-IL6 are both in GPE1. GPE3 is a G-CSF-specific sequence and mutations in its corresponding region cause a 6 - to 50 -fold reduction in its activity (31). In addition, there are two destabilizing elements in the $3^{\prime}$ untranslated region of G-CSF mRNA, including adenylate uridylate-rich element and stem-loop destabilizing element (32).

It has been acknowledged that there are two different G-CSF mRNA isoforms in humans: G-CSFa and G-CSFb. Compared with G-CSFa, G-CSFb lacks 9 base pairs (GTGAGTGAG) in the second exon (21). G-CSFa and G-CSFb mRNAs encode polypeptides that consist of 207 and 204 amino acids, respectively. After cleavage of the 30 -amino acid signal peptide, mature proteins containing 177 and 174 amino acids are secreted. Arakawa et al (33), found that the activity of the 174-amino acid form is 50 -fold higher than that of the 177-amino acid form. The secreted form of the protein was found to be O-glycosylated and to have a molecular weight of 19,600 Da (34). One O-linked glycosyl group at Thr 133 in G-CSF isolated from human blood protects the molecule from aggregation (35).

The G-CSF protein contains five cysteines and two pairs of disulfide bonds are formed between residues Cys 36 and Cys42 and residues Cys 74 and Cys64. The disulfide bonds play an important role in maintaining the biological functions of G-CSF. Within the G-CSF protein, 104 of the 175 residues form a total of four $\alpha$-helix bundles that are designated helix A (residues 11-39), B (71-91), C (100-123) and D (143-172) (36). A study of the three-dimensional crystal structure of recombinant interferon (IFN)- $\beta$ suggested that the receptor binding region of G-CSF is located on the loop connecting helix A and $B$ and on the outer surface of helix D (37). 


\section{Regulation of G-CSF gene expression}

Under physiological conditions, the G-CSF concentration in plasma is almost undetectable, but when an infection occurs, the G-CSF concentration is significantly increased. The number of neutrophils is dependent on the G-CSF concentration, especially during the infection process or chemotherapy use (38). G-CSF can be secreted by numerous cells, including monocytes, macrophages, endothelial cells, epithelial cells and fibroblasts, when they are stimulated by inflammatory mediators such as LPS (39), IL-17 (40), TNF- $\alpha$ and IFN- $\beta$ (41). Moreover, some malignant cells, such as triple-negative breast cancer (17), lung carcinoma (42,43), bladder cancer (44) and squamous cell carcinoma (45), can constitutively express and secrete G-CSF.

G-CSF expression in breast cancer is under the control of various signaling pathways. It has been reported that carbonic anhydrase IX (CAIX) stimulates G-CSF production by activating NF- $\mathrm{KB}$ signaling in hypoxic conditions (46). Extracellular signal-regulated kinase (ERK) 2 is responsible for the transcriptional regulation of G-CSF and ERK2 knockdown by short hairpin RNA significantly inhibits the expression of tumor-derived G-CSF (47). H-Ras upregulates G-CSF expression and promotes breast epithelial MCF10A cell invasiveness (48). Protease-activated receptor (PAR) 2 stimulates G-CSF expression in breast cancer and PAR2 gene knockdown or PAR2 antagonist use can reduce G-CSF secretion (49). Carcinoembryonic antigen-related cell adhesion molecule (CEACAM) 1 expression in breast cancer MCF-7 cells inhibits G-CSF secretion by M1 macrophages (50). In addition, G-CSF is the main downstream mediator of the mammalian target of rapamycin (mTOR) pathway during the induction of myeloid-derived suppressor cell (MDSC) formation in breast cancer and Welte et al (51), suggested that the regulation of G-CSF by mTOR may occur at the transcriptional level. In other diseases, some factors have been shown to regulate G-CSF expression, all of which are shown in Table I.

\section{The G-CSF receptor}

The G-CSFR gene located on chromosome $1 \mathrm{p} 35-34.3$ is a member of the class I cytokine receptor superfamily (52). G-CSFR is a single transmembrane protein consisting of 813 amino acid residues, which is composed of extracellular, transmembrane and intracellular regions. Its extracellular region includes immunoglobulin-like (Ig-like) domains and cytokine receptor homology $(\mathrm{CRH})$ domains, as well as three fibronectin type III domains. The intracellular region of G-CSFR protein includes two motifs called box 1 and box 2 , and cytoplasmic region of G-CSFR contains four conserved tyrosine residues which function as docking sites for the phosphorylation of multiple SH2-containing signaling proteins (53). G-CSF binds to the extracellular Ig-like and CRH domains of G-CSFR, which triggers receptor homodimerization (54) and activates Janus tyrosine kinases (JAKs), leading to a cross-phosphorylation. Activated JAKs proteins can phosphorylate G-CSFR by binding to its Box 1 and 2 domains and generate potential docking sites of signal transducer and activator of transcription (STAT) protein in cytoplasm. The inactive STAT protein binds to the phosphorylated G-CSFR through its SH2 domain and phosphorylates it under the cooperation with JAKs (55). Activated STATs then form a homodimer/heterodimer and translocate into the nucleus to activate the transcription of target genes, which promote the proliferation and metastasis of cancer cells (56). Although the G-CSF-induced JAK2/STAT3 pathway has been well-established (57), previous studies also show that G-CSF can activate other downstream signaling pathways, including mitogen-activated protein kinase (MAPK)/ERK and phosphatidylinositol 3 kinase/protein kinase B (AKT) $(54,58)$.

\section{G-CSF expression in breast cancer}

Some studies have reported that serum G-CSF levels are significantly higher in breast cancer patients compared with healthy controls $(48,59-63)$. Lawicki et al (60), demonstrated that the plasma levels of G-CSF and M-CSF were significantly increased in 54 breast cancer patients compared with in control group patients. The authors of the present review were surprised to learn that, after surgical resection, the level of G-CSF decreased significantly, but the level of M-CSF increased, suggesting that measuring G-CSF may be useful in the diagnosis of breast cancer. Compared with 20 healthy controls, the mean level of serum G-CSF in 20 breast cancer patients was significantly increased (48). In a total of 190 samples, plasma G-CSF levels were significantly increased in samples from 110 patients with ductal breast cancer and 40 patients with benign breast cancer compared with samples from untreated healthy patients. Moreover, the serum levels of G-CSF were significantly increased in patients with clinical stage III and IV tumors compared with in healthy controls or patients with benign breast cancer (61). In addition, in a total of 196 samples, serum G-CSF levels were increased in patients with advanced breast cancer compared with in patients with early-stage cancer and the highest G-CSF levels were observed in patients with N3 tumors (62). By analyzing the wound healing fluid of breast cancer surgery patients, it was found that G-CSF, together with IL-6 and monocyte chemotactic protein (MCP)-1/CCL2, was more abundant in invasive and high-grade breast cancer than in situ breast cancer (63).

Wojtukiewicz et al (64), also reported that G-CSFR was expressed in only breast cancer tissues, not in normal breast tissues and its expression level was as high as $71 \%$ in the collected clinical specimens. Notably, high G-CSFR expression was observed in $21 \%$ of cases, especially in cases involving small focal invasive breast cancer. In addition, other studies have confirmed the expression of G-CSF in breast cancer tissues and its association with breast cancer invasion $(17,46,65,66)$. Within a larger group of human breast cancer samples $(\mathrm{n}=548)$, triple-negative breast cancer was shown to exhibit higher G-CSF expression, which was related to cluster of differentiation (CD)163+ macrophages and associated with a poorer overall survival rate, than other types of breast cancer (17). Compared with noninvasive breast cancer T47D and MCF-7 cells, invasive MDA-MB-231 cells exhibit higher G-CSF expression (47), which suggests that the association between G-CSF expression and malignant disease should be explored.

Through The Cancer Genome Atlas data analysis, Guo et al (67) discovered a high-risk luminal A dominant breast 
Table I. Regulation of G-CSF gene expression.

\begin{tabular}{|c|c|c|c|c|}
\hline Author, year & Cell type & Producer cell and contexts & Inducer (+) / inhibitor (-) & (Refs.) \\
\hline Park et al, 2011 & \multirow[t]{10}{*}{ Tumor cells } & Human MCF10A cells & $+\mathrm{H}-\mathrm{Ras}$ & $(48)$ \\
\hline Lee et al, 2013 & & Human MDA-MB-231 breast cancer cells & + ERK2 & $(47)$ \\
\hline Chafe et al, 2015 & & $\begin{array}{l}\text { Hypoxic breast cancer cells } \\
\text { and tumors in an orthotopic model }\end{array}$ & + CAIX & (46) \\
\hline Carvalho et al, 2018 & & Mouse 4T1 and human MDA-MB-231 cells & + PAR2 & $(49)$ \\
\hline Welte et al, 2016 & & Mouse P53N-A and 4T1 breast cancer cells & + mTOR & $(51)$ \\
\hline Cao et al, 2014 & & Mouse mammary tumors & - BMP4 & $(65)$ \\
\hline Uemura et al, 2005 & & Human lung cancer OKa-C-1 and MI-4 cells & $+\mathrm{PKC}$ inhibitor & $(43)$ \\
\hline Nakata et al, 2003 & & Human lung cancer cells & - NS-398 & $(100)$ \\
\hline Cui et al, 2015 & & Human non-small-cell lung cancer cells & + Radiation, $\beta$-catenin & $(101)$ \\
\hline Pickup et al, 2017 & & Human pancreatic ductal adenocarcinomas & - TGF- $\beta$ signaling & $(81)$ \\
\hline Ramakrishna et al, 2018 & \multirow[t]{18}{*}{ Immune cells } & Human CD11b+ macrophages and neutrophils & $-\mathrm{IFN}-\gamma$ & $(102)$ \\
\hline Chang et al, 2016 & & Human macrophages & + SB203580 & $(103)$ \\
\hline Samineni et al, 2013 & & Human breast tumor-associated macrophages & - CEACAM1 & $(50)$ \\
\hline Fujimoto et al, 2011; & & Human macrophage RAW 264 cells & - SOCS1 & $(104)$ \\
\hline Kamio et al, 2008; & & & + Adiponectin & $(105)$ \\
\hline Zhang et al, 2011 & & & - HSF1 & $(106)$ \\
\hline He et al, 2009; & & Human monocytes and macrophages & + SAA & $(22)$ \\
\hline Hareng et al, 2003 & & & + cAMP & (29) \\
\hline Aoki et al, 1998; & & Mouse macrophage cell line & + Fibronectin, vitronectin & $(107)$ \\
\hline Chou et al, 2011 & & & + LTA, - rapamycin & $(108)$ \\
\hline Sallerfors et al, 1992; & & Human monocytes & + LPS, +IL-1, +GM-CSF, & $(109)$ \\
\hline Vellenga et al, 1988; & & & $+\mathrm{TNF}$ & (39) \\
\hline Motz et al, 2013; & & & + LPS & $(77)$ \\
\hline Almand et al, 2001 & & & $\begin{array}{l}+ \text { CSF-HU, } \\
+ \text { IL-4 }\end{array}$ & (78) \\
\hline Tajuddin et al, 2010 & & Human peripheral blood mononuclear cells & + TLR7/8 agonist (CL097), - IFN- $\alpha$ & $(110)$ \\
\hline Ichinose et al, 1990 & & Human neutrophils & + LPS & $(111)$ \\
\hline Lindemann et al, 1989 & & Human polymorphonuclear leukocytes & $+\mathrm{GM}-\mathrm{CSF}$ & $(112)$ \\
\hline Lu et al, 1988 & & Human T lymphocytes & $+\mathrm{IFN}-\gamma, \mathrm{IL}-1 \beta$ & (113) \\
\hline Meixner et al, 2008; & \multirow[t]{8}{*}{ Epithelial cells } & Human epidermal cells & - JunB & (91) \\
\hline Lennard et al, 2016; & & & + Fli-1 & (114) \\
\hline Rajavashisth et al, 1990; & & & + Modified low-density lipids & $(115)$ \\
\hline Seelentag et al, 1987 & & & + IL-1 and TNF- $\alpha$ & $(116)$ \\
\hline Saba et al, 2002; & & Human airway epithelial cells & + Bacterial (P. aeruginosa and S. aureus) & $(117)$ \\
\hline Jones et al, 2002; & & & $+\mathrm{IL}-17, \mathrm{TNF}-\alpha$ & $(40)$ \\
\hline Suzukawa et al, 2015 & & & + Leptin & $(118)$ \\
\hline Numasaki et al, 2004 & & Human lung microvascular endothelial cells & $\begin{array}{l}+\mathrm{IL}-17, \mathrm{TNF}-\alpha, \mathrm{IL}-1 \beta \\
-\mathrm{IL}-17 \mathrm{~F}\end{array}$ & (119) \\
\hline Witowski et al, 2007 & \multirow[t]{2}{*}{ Mesothelial cells } & Human peritoneal mesothelial cells & $+\mathrm{IL}-17, \mathrm{TNF}-\alpha$ & $(120)$ \\
\hline Demetri et al, 1989 & & Human mesothelial cells & + EGF, LPS & $(121)$ \\
\hline Carr et al, 2017; & \multirow[t]{5}{*}{ Fibroblasts } & Human dermal fibroblasts & $+\mathrm{IL}-1$ & $(122)$ \\
\hline Ramachandran et al, 2006 & & Human bronchial fibroblasts & + PAR2 agonists & $(123)$ \\
\hline Himes et al, 1993; & & Human fibroblasts & $+\operatorname{Tax}$ & $(23)$ \\
\hline Koeffler et al, 1987; & & & $+\mathrm{TNF}-\alpha$ & (124) \\
\hline Seelentag et al, 1989 & & & $+\mathrm{IL}-1 \beta$ & $(125)$ \\
\hline Zgheib et al, 2013 & \multirow[t]{2}{*}{ Stem cells } & Human mesenchymal stromal cells & + ConA, MT1-MMP inducer & $(126)$ \\
\hline Fibbe et al, 1988 & & Human marrow stromal cells & $+\mathrm{IL} 1$ & $(127)$ \\
\hline Tesio et al, 2013 & \multirow{3}{*}{$\begin{array}{l}\text { Bone marrow - } \\
\text { derived cells }\end{array}$} & Human myeloid cells & - PTEN & $(128)$ \\
\hline Grace et al, 2012 & & Human hematopoietic progenitor cells & $+5-\mathrm{AED}$ & (129) \\
\hline Kimura et al, 2004 & & Mouse bone marrow & - SOCS3/CIS3 & $(130)$ \\
\hline Smith et al, 2017 & \multirow[t]{2}{*}{ Others } & Human first-trimester trophoblast cells (Sw.71) & - Cortisol & $(131)$ \\
\hline Ordelheide et al, 2016 & & Human myoblasts & + Palmitate, stearate & $(132)$ \\
\hline
\end{tabular}


Table I. Continued.

\begin{tabular}{|c|c|c|c|c|}
\hline Author, year & Cell type & Producer cell and contexts & Inducer (+) / inhibitor (-) & (Refs.) \\
\hline Hudock et al, 2012; & & Mouse intraplantar tissue & + LPS, IL-1, IL-17A & (133) \\
\hline Soria-Castro et al, 2010 & & & $+\mathrm{Cot} / \mathrm{tpl} 2$ & (134) \\
\hline Janelle et al, 2006 & & Mouse lung tissue & + Pre-elafin & (135) \\
\hline Bohannon et al, 2016 & & - & + Monophosphoryl lipid A & (136) \\
\hline Ellis et al, 2005 & & - & $+\mathrm{FRH}$ & (137) \\
\hline
\end{tabular}

TNF- $\alpha$, tumor necrosis factor- $\alpha$; CAIX, carbonic anhydrase IX; ConA, concanavalin A; SOCS1/CIS3, suppressor of cytokine signaling-1; HSF1, heat shock factor 1 ; IFN- $\alpha$, interferon- $\alpha$; SAA, serum amyloid A; FRH, febrile-range hyperthermia; SOCS3/CIS3, cytokine signaling-3; 5-AED, 5-Androstenediol; PAR2, protease-activated receptor 2; Fli-1, friend leukemia insertion site 1; Tax, transactivator protein; LTA, lipoteichoic acid; CSF-HU, human urinary colony-stimulating factor; EGF, epidermal growth factor; LPS, lipopolysaccharide; IL, interleukin.

cancer subtype with increased motility (C3) that exhibited high G-CSF expression with neutrophil aggregation. Cancer cells that produced high G-CSF levels could stimulate neutrophils to form neutrophilic extracellular traps (NETs) and thereby promote cancer cell migration. G-CSF secreted by 4T1 cells can stimulate neutrophils to form NETs and the anti-G-CSF antibody reduces cancer cell-induced NET formation (68). In addition, anti-G-CSF treatment results in the hypercitrullination of histone $\mathrm{H} 3$ in neutrophils from cancer-free mice, which increases the susceptibility to NETosis and thrombolysis (69).

Cancer-related thrombosis is the second leading cause of death and is usually associated with poor prognosis in cancer patients. NET formation is crucial for thrombosis formation in tumor-bearing mice. 4T1 cell-derived exosomes induce NET formation in neutrophils from G-CSF-treated mice, which can promote thrombus formation in tumor-free neutrophilic mice. The results suggested that tumor-derived exosomes and neutrophils play a synergistic role in the formation of cancer-associated thrombosis (70). Demers et al (15), discovered that cancer-associated G-CSF exacerbates the innate immune response of the host which leads to thrombosis. NET formation induces a pro-thrombotic state which may result in the consumption of platelets, clotting factors and microthrombosis in rhG-CSF-treated 4T1 mice. IL-1 $\beta$ modulates the expression of G-CSF and the levels of G-CSF and IL-1 $\beta$ are elevated in 4T1 mice which exhibit a NET-dependent prothrombotic state. Blocking IL-1R reduces the G-CSF level, NET formation and abolishes the pre-thrombotic state in 4T1 tumor-bearing mice (16).

\section{Direct effects of G-CSF on breast cancer}

rhG-CSF was shown to promote the proliferation of MCF-7 and SKBR-3 breast cancer cells, but it had little effect on normal breast epithelial cells. Chronic exposure to low doses of rhG-CSF $(0.125 \mu \mathrm{g})$ promotes tumorigenesis in estrogen receptor-positive breast cancer by promoting the proliferation of normal and precancerous tissues in MMTV-erbB2 mice (71). Waight et al (72), showed that tumor-derived G-CSF can directly promote tumor growth and G-CSF knockdown slows tumor growth in mouse breast tumor models. G-CSF, in combination with other proinflammatory cytokines such as GM-CSF, IL-8 and MCP-1 that are secreted by highly aggressive tumor cells, induces an epithelial mesenchymal transition/stemness-like invasive phenotype in nonaggressive breast cancer cells (73). Higher G-CSF expression increases the invasiveness of breast and lung cancer cells, and ERK2 inhibition is necessary to reduce the expression of TNF- $\alpha$-induced G-CSF in aggressive cancer cells (47). These results indicate that G-CSF is a critical factor that promotes breast tumorigenesis and specific ERK2 inhibitors may be used to treat G-CSF-producing tumors.

G-CSF-induced invasiveness in breast epithelial MCF10A cells is closely related to H-Ras oncogene upregulation. Stable expression of G-CSF induced by $\mathrm{H}$-Ras upregulates matrix metalloproteinase (MMP)-2 expression by activating Rac 1 and promotes MCF10A cell migration/invasion. MMP-2-mediated degradation of extracellular matrix components is a key step in the development of invasiveness. Overexpression of G-CSF in MCF10A cells also activates other signaling pathways, including MKK3/6, p38 MAPK, ERK1/2 and AKT (48). The results of a serological in vivo analysis of breast cancer patients were also consistent with observations made in vitro, suggesting that G-CSF may be used as a serum indicator in the treatment of breast cancer (48).

G-CSF induces ErbB2 expression in breast cancer cell lines. The present review was surprised that the binding of both trastuzumab and G-CSF inhibits tumor colony formation and simultaneously induces apoptosis in these cells. This inhibition is more pronounced after pretreatment with G-CSF. A total of five of the nine breast cancer patients showed an increase in their Herceptest scores, which were used to detect ErbB2 expression after G-CSF administration (74). The ErbB2 (HER2) proto-oncogene encodes a tyrosine kinase receptor that is overexpressed in $15-20 \%$ of human breast cancer cases with aggressive clinical behavior (75).

\section{Role of tumor microenvironment in the effect of G-CSF on breast cancer}

Breast cancer is the most common form of cancer in women worldwide (76). The interaction between breast cancer cells and the tumor microenvironment is crucial for the dynamic development of tumors. The malignant progression of tumors depends mainly on evading and inhibiting host immune 
responses, which can be achieved through stimulation of the immunosuppressive activity of MDSCs $(77,78)$. MDSCs are a heterogeneous population defined as CD11b+Gr1+ cells, which are divided into monocytic and granulocytic subsets using the markers Ly6G and Ly6C, respectively. MDSCs can mobilize and infiltrate into tumors during tumorigenesis, where they promote tumor angiogenesis and induce premetastatic niche formation. They also interrupt mechanisms of immune surveillance, including antigenic presentation by dendritic cells (DCs), T cell activation, M1 macrophage polarization and NK cell cytotoxicity inhibition (79), in multiple tumor types, such as glioma (80) and pancreatic ductal adenocarcinoma (81). It has been reported that MDSCs accumulate around tumors and the level of circulating MDSCs is correlated with the clinical grade, metastasis and therapy response in solid tumors $(82,83)$.

MDSCs can be induced by G-CSF treatment or by G-CSF secretion from tumors (65). Tumor-derived G-CSF facilitates the generation of granulocytic MDSCs in breast cancer, which effectively inhibit $\mathrm{T}$ cell activation and proliferation, leading to metastatic enhancement (72). BMP4, a member of the transforming growth factor (TGF)- $\beta$ growth factor family, suppresses G-CSF secretion by inhibiting the activity of NF- $\kappa \mathrm{B}$ in tumor lines, resulting in decreases in MDSCs in human and mouse breast cancer (65).

Studies have found that G-CSF promotes MDSC accumulation in breast cancer via the mTOR signaling pathway. Reverse-phase protein array analysis in mammary tumor models revealed that MDSC accumulation is accompanied by increased AKT-mTOR signaling pathway activity and induces G-CSF expression in cancer cells. Surprisingly, the expression of G-CSF in tumor-initiating cells (TICs) is high and MDSCs facilitate the expression of stemness-related genes in cancer cells, including Nanog, LGR5 and MSI-1. Moreover, MDSCs stimulate improved TIC performance via the Notch signaling pathway and TICs promote G-CSF enhancement and thus increase MDSC accumulation, which therefore establishes a feed-forward loop between TICs and MDSCs. In addition, mice treated with the mTOR inhibitor rapamycin showed significant tumor growth delay. These data demonstrate that the mTOR/G-CSF/MDSC signaling pathway regulates the malignant progression of breast tumors (51). Tumor-secreted G-CSF can increase the number of Ly6G+Ly6C+ granulocytes, which are a subset of CD11b+Gr1+ cells, in organ-specific transfer sites and further promote the production of the proangiogenic factor $\mathrm{Bv} 8$ protein to enhance breast tumor metastasis. Anti-G-CSF treatment can significantly reduce lung metastasis in mammary carcinoma models (66).

The hypoxic tumor microenvironment is conducive to driving metastatic niche development (84). Breast tumor cell exposure to a hypoxic microenvironment results in the activation of hypoxia-inducible factor (HIF)-1/2-mediated transcriptional programs that mediate adaptive responses in cells. Chafe et al (46), first revealed the relationship between the CAIX-NF- $\kappa \mathrm{B}-\mathrm{G}-\mathrm{CSF}$ cell signaling axis and breast cancer lung metastasis. In the absence of oxygen, the expression of CAIX in breast cancer is significantly upregulated due to $\mathrm{HIF}-1$ activation. NF- $\kappa \mathrm{B}$ activation in the microenvironment is critical for the expression of CAIX, which is required for the G-CSF-driven mobilization of granulocytic MDSCs to the breast cancer-derived lung metastatic niche. Constitutive
NF- $\kappa \mathrm{B}$ activation can normalize the secretion of G-CSF, even if CAIX is completely consumed. Mobilized G-CSF-dependent granulocytic MDSCs can enhance the growth and proliferation of disseminated tumor cells to promote the formation of lung metastasis via immunosuppression (46).

Tumor-associated macrophages (TAMs) play an extremely important role in the tumor microenvironment. Macrophages in the peripheral circulation are recruited to the tumor area as a result of the action of chemokines and cytokines, such as MCP-1, M-CSF, CCL8 and vascular epithelial growth factor (VEGF), which are secreted by tumor cells or the tumor stroma. M-CSF (CSF-1) is a major contributor to TAM infiltration and promotes tumor growth (85). Blockade of the M-CSF/CSF-1R signaling pathway suppresses tumor growth in mammary carcinoma models (86) and targeting TAMs with a CSF-1R antibody is a viable strategy for cancer therapy (87).

According to Hollmén et al (17), high G-CSF expression in heterogeneous triple-negative breast cancer is closely associated with seeding metastasis and low overall survival. G-CSF, similar to M-CSF, regulates the differentiation of monocytes into TAMs that resemble alternatively activated (M2) macrophages. M2-polarized macrophages are characterized by a tolerant phenotype that promotes tissue repair and vasculogenesis and supports tumor growth (88). By acting on the G-CSFR on the surface of TAMs, G-CSF increases TGF- $\alpha$ secretion to promote breast tumor cell migration. Interestingly, in the 4T1 mammary tumor model, which is known to secrete high levels of G-CSF, an anti-G-CSF antibody significantly reduced tumor growth and lung metastasis incidence and burden. However, anti-CSF-1R promoted tumor growth and enhanced lymph node and lung metastasis. Blockade of both G-CSF and CSF-1R partly reduced lung metastasis but significantly increased lymph node metastasis, which suggests that different mechanisms may underlie lung metastasis seeding and lymph node metastasis. A possible explanation for this is that CD169+ macrophages are important gatekeeper cells in the subcapsular sinus, where they prevent the systemic dissemination of pathogens. Depletion of CD169+ macrophages in the subcapsular sinus via treatment with anti-CSF-1R or a combination of anti G-CSF and anti-CSF-1R increased lymph node metastasis, mainly because CSF-1R is the major growth factor for CD169+ macrophages in the subcapsular sinus. This important discovery suggests that M-CSF/CSF-1R-targeted inhibitors should be used with caution in the presence of high G-CSF levels (17). Similarly, the inhibition of M-CSF/CSF-1R signaling increases spontaneous lung and bone metastasis without altering tumor growth in mouse 4T1 mammary tumors, which is associated with increased serum G-CSF levels and increased neutrophil numbers at multiple sites. However, targeting G-CSF receptors with neutralizing antibodies reversed this effect, indicating that the facilitation of metastasis is driven by G-CSF in the 4T1 mammary tumor model (89).

CEACAM1 is a cell adhesion molecule that is downregulated in numerous cancers that originate from the epithelium (90). CEACAM1 plays a role in inhibiting inflammation, partly by inhibiting G-CSF production by myeloid cells. The lack of CEACAM1 expression in breast tumors promoted the secretion of high levels of G-CSF by TAMs, which in turn promoted tumor angiogenesis and initial tumor 


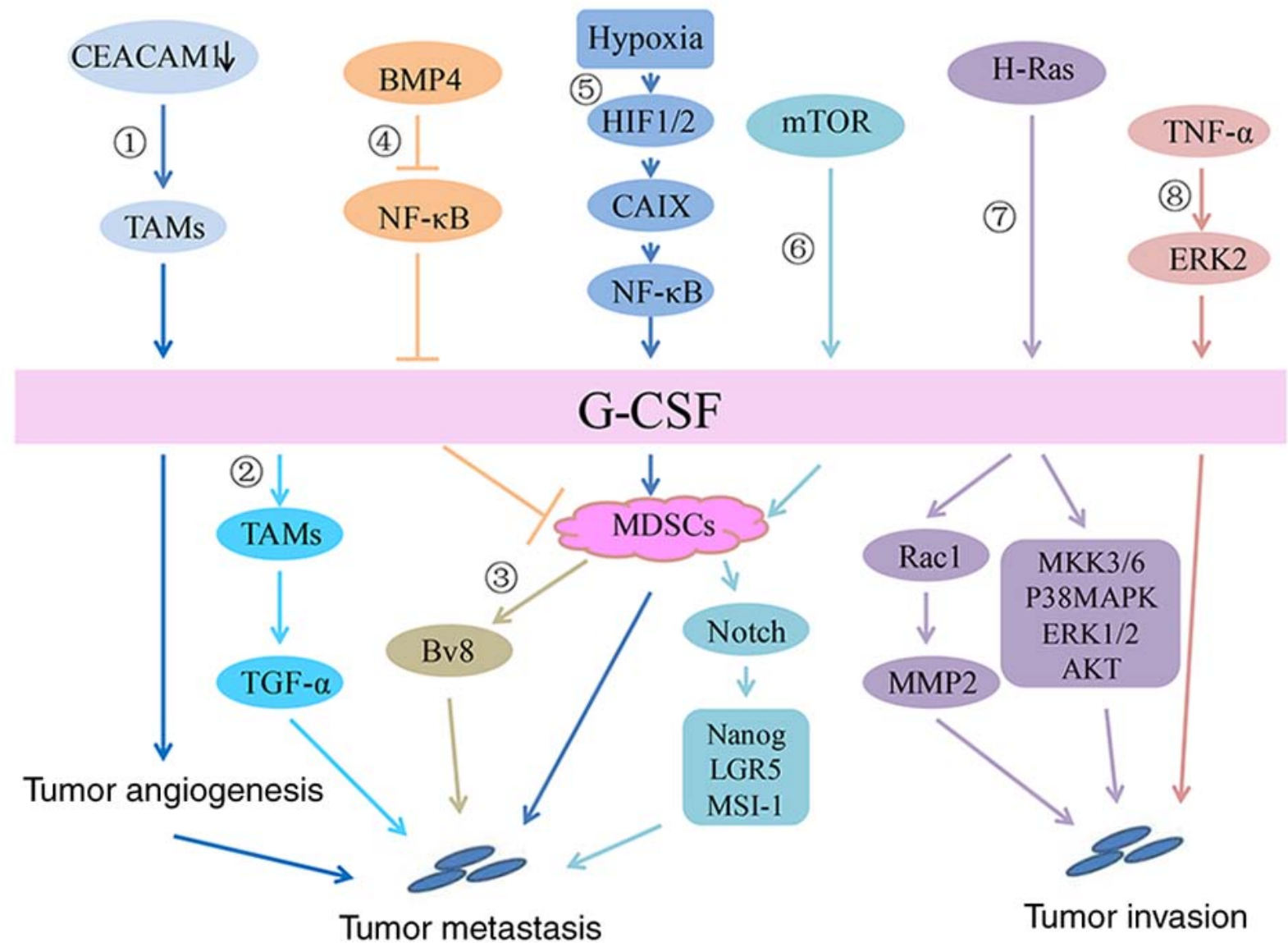

Figure 2. Signaling pathway of G-CSF in breast cancer. In the breast cancer microenvironment: 1) CEACAM1 downregulation promotes G-CSF secretion by TAMs, thereby promoting tumor angiogenesis and initial tumor establishment. 2) By acting on G-CSFR on TAMs, G-CSF increases transforming growth factor- $\alpha$ secretion to promote tumor cell migration. 3) G-CSF increases Ly6G+Ly6C+ granulocytes, which are a type of MDSC and further promotes the production of the proangiogenic factor Bv8 to enhance breast tumor metastasis. 4) BMP4 inhibits the expression and secretion of G-CSF by inhibiting NF- $\mathrm{kB}$, resulting in decreases in the number and activity of MDSCs. 5) In a hypoxic environment, HIF1/2 upregulates CAIX and increases G-CSF expression by activating the NF- $\mathrm{KB}$ signaling pathway, which then promotes the mobilization of MDSCs and eventually leads to the lung metastasis of breast cancer. 6) Activation of the AKT-mTOR signaling pathway increases G-CSF expression in tumor cells, thereby promoting the accumulation of MDSCs. MDSCs promote the expression of stem-associated genes, including Nanog, LGR5 and MSI-1, in cancer cells via Notch signaling to promote tumor progression. Direct effect of G-CSF on breast cancer: 7) Stable expression of G-CSF induced by H-Ras upregulates the expression of MMP-2 by activating Rac 1 and promotes the migration/invasion of breast epithelial cells. In addition, overexpression of G-CSF activates other signaling pathways, including MKK3/6, p38 MAPK, ERK1/2 and AKT, thus promoting an invasive phenotype in breast epithelial cells. 8) TNF- $\alpha$ promotes the expression of G-CSF by activating the ERK2 signaling pathway to promote tumor invasion. TNF, tumor necrosis factor; AKT, protein kinase B; G-CSF, granulocyte-colony stimulating factor; HIF, hypoxia inducible factor; MAPK, mitogen associated protein kinase; NF, nuclear factor; mTOR, mammalian target of rapamycin; MDSC, myeloid-derived suppressor cell; CAIX, carbonic anhydrase IX; MMP, matrix metalloproteinase; ERK, extracellular signal regulated kinase; TAM, tumor-associated macrophages; CEACAM1, carcinoembryonic antigen-related cell adhesion molecule 1.

establishment. It has been suggested that G-CSF plays an important role in tumor promotion induced by CEACAM1 downregulation (50). Generally, as shown in Fig. 2, G-CSF plays a crucial role in breast cancer malignant progression.

\section{Conclusions}

G-CSF stimulates the proliferation and survival of hematopoietic stem progenitor cells and their differentiation into neutrophils by acting on their specific receptor G-CSFR. Under physiological conditions, G-CSF affects the mobilization of hematopoietic stem cells, progenitor cells and mature cells, especially neutrophils, to the blood circulation. When the body is infected, the serum G-CSF level is significantly increased to promote neutrophil mobilization to the peripheral circulation. Therefore, rhG-CSF can be used to treat neutropenia induced by chemotherapy and radiation therapy.
As an adjunct to cancer therapy, G-CSF induces ErbB2 proto-oncogene expression in breast cancer patients, making it an effective drug for improving the sensitivity of breast cancer patients to trastuzumab (91). Currently, an increasing number of studies have found that tumors with high G-CSF expression show significant proliferative and metastatic properties and lead to poor prognosis $(17,47,48,67)$. Therefore, the safety of G-CSF as an adjunct to cancer treatment should be addressed.

Some basic studies have shown that G-CSF is a promoter of tumor growth, which plays a role in immunosuppression by increasing tumor angiogenesis and mobilizing MDSCs (13,14,46,51,72). Kim et al (92), confirmed that G-CSF treatment in mice with precise focused radiation promoted tumor growth by stimulating angiogenesis in tumor-bearing mice and reduced the antitumor effect of radiotherapy. Coincidentally, in cervical cancer patients treated with platinum-based chemotherapy drugs, G-CSF expression in tumors 
is an indicator of poor prognosis in patients. Secreted G-CSF not only has an antiapoptotic effect but also promotes the formation of tumors by mobilizing MDSCs to inhibit T cell activity and Bv8 secretion (12). In some clinical case reports, the use of safe therapeutic doses of G-CSF may cause unpredictable side effects such as bone pain, local skin reactions at the injection site and even spleen rupture or infarction (93-96). This evidence also raised concerns for clinical work. Effective methods are needed to evaluate the G-CSF usage window.

The JAK/STAT signal transduction pathway has been shown to be an important downstream pathway for G-CSF regulation in cancer models such as colorectal cancer and is inseparable from cancer proliferation and migration (57,97-99). Studying the relationship between the G-CSF-JAK/STAT signaling pathway and breast cancer can provide new insights for targeted breast cancer therapy and its prognostic strategies.

\section{Acknowledgements}

The authors of the present study would like to thank Professor Daya Luo (Department of Biochemistry and Molecular Biology, School of Basic Medical Sciences, Nanchang University), who made valuable suggestions regarding this manuscript.

\section{Funding}

The present review was supported by grants from the National Natural Science Foundation of China (grant no. 81760509) and the Natural Science Foundation of Jiangxi Province of China (grant no. 20181BAB205043).

\section{Availability of data and materials}

Not applicable.

\section{Authors' contributions}

LL and YL wrote the manuscript, prepared the figures and repeatedly revised the paper. $\mathrm{CZ}$ collected the articles regarding G-CSF expression. XX and XY reviewed drafts of the paper. All authors read and approved the final manuscript.

\section{Ethics approval and consent to participate}

Not applicable.

\section{Patient consent for publication}

Not applicable.

\section{Competing interests}

The authors declare that they have no competing interests.

\section{References}

1. Bradley TR and Metcalf D: The growth of mouse bone marrow cells in vitro. Aust J Exp Biol Med Sci 44: 287-299, 1966.

2. Ichikawa Y, Pluznik DH and Sachs L: In vitro control of the development of macrophage and granulocyte colonies. Proc Natl Acad Sci USA 56: 488-495, 1966.
3. Stanley ER and Heard PM: Factors regulating macrophage production and growth. Purification and some properties of the colony stimulating factor from medium conditioned by mouse $\mathrm{L}$ cells. J Biol Chem 252: 4305-4312, 1977.

4. Burgess AW, Camakaris J and Metcalf D: Purification and properties of colony-stimulating factor from mouse lung-conditioned medium. J Biol Chem 252: 1998-2003, 1977.

5. Nicola NA, Metcalf D, Matsumoto $M$ and Johnson GR: Purification of a factor inducing differentiation in murine myelomonocytic leukemia cells. Identification as granulocyte colony-stimulating factor. J Biol Chem 258: 9017-9023, 1983.

6. Ihle JN, Keller J, Henderson L, Klein F and Palaszynski E: Procedures for the purification of interleukin 3 to homogeneity. $\mathrm{J}$ Immunol 129: 2431-2436, 1982.

7. Metcalf D: The colony stimulating factors. Discovery, development, and clinical applications. Cancer 65: 2185-2195, 1990.

8. Fukunaga R, Ishizaka-Ikeda E and Nagata S: Purification and characterization of the receptor for murine granulocyte colony-stimulating factor. J Biol Chem 265: 14008-14015, 1990.

9. Demetri GD and Griffin JD: Granulocyte colony-stimulating factor and its receptor. Blood 78: 2791-2808, 1991.

10. Bendall LJ and Bradstock KF: G-CSF: From granulopoietic stimulant to bone marrow stem cell mobilizing agent. Cytokine Growth Factor Rev 25: 355-367, 2014.

11. Mitchell S, Li X, Woods M, Garcia J, Hebard-Massey K, Barron R and Samuel M: Comparative effectiveness of granulocyte colony-stimulating factors to prevent febrile neutropenia and related complications in cancer patients in clinical practice: A systematic review. J Oncol Pharm Pract 22: 702-716, 2016.

12. Kawano M, Mabuchi S, Matsumoto Y, Sasano T, Takahashi R, Kuroda H, Kozasa K, Hashimoto K, Isobe A, Sawada K, et al: The significance of G-CSF expression and myeloid-derived suppressor cells in the chemoresistance of uterine cervical cancer. Sci Rep 5: 18217, 2015.

13. Okazaki T, Ebihara S, Asada M, Kanda A, Sasaki H and Yamaya M: Granulocyte colony-stimulating factor promotes tumor angiogenesis via increasing circulating endothelial progenitor cells and Gr1+CD11b+ cells in cancer animal models. Int Immunol 18: 1-9, 2006.

14. Shojaei F, Wu X, Qu X, Kowanetz M, Yu L, Tan M, Meng YG and Ferrara N: G-CSF-initiated myeloid cell mobilization and angiogenesis mediate tumor refractoriness to anti-VEGF therapy in mouse models. Proc Natl Acad Sci USA 106: 6742-6747, 2009.

15. Demers M, Krause DS, Schatzberg D, Martinod K, Voorhees JR, Fuchs TA, Scadden DT and Wagner DD: Cancers predispose neutrophils to release extracellular DNA traps that contribute to cancer-associated thrombosis. Proc Natl Acad Sci USA 109: 13076-13081, 2012.

16. Gomes T, Várady CBS, Lourenço AL, Mizurini DM, Rondon AMR, Leal AC, Gonçalves BS, Bou-Habib DC, Medei E and Monteiro RQ: IL-1 $\beta$ blockade attenuates thrombosis in a neutrophil extracellular trap-dependent breast cancer model. Front Immunol 10: 2088, 2019.

17. Hollmén M, Karaman S, Schwager S, Lisibach A, Christiansen AJ, Maksimow M, Varga Z, Jalkanen S and Detmar M: G-CSF regulates macrophage phenotype and associates with poor overall survival in human triple-negative breast cancer. OncoImmunology 5: e1115177, 2015.

18. Kanda N, Fukushige S, Murotsu T, Yoshida MC, Tsuchiya M, Asano S, Kaziro Y and Nagata S: Human gene coding for granulocyte-colony stimulating factor is assigned to the q21-q22 region of chromosome 17. Somat Cell Mol Genet 13: 679-684, 1987.

19. Tsuchiya M, Kaziro Y and Nagata S: The chromosomal gene structure for murine granulocyte colony-stimulating factor. Eur J Biochem 165: 7-12, 1987.

20. Shannon MF, Pell LM, Lenardo MJ, Kuczek ES, Occhiodoro FS, Dunn SM and Vadas MA: A novel tumor necrosis factor-responsive transcription factor which recognizes a regulatory element in hemopoietic growth factor genes. Mol Cell Biol 10: 2950-2959, 1990.

21. Nagata S, Tsuchiya M, Asano S, Yamamoto O, Hirata $Y$, Kubota N, Oheda M, Nomura H and Yamazaki T: The chromosomal gene structure and two mRNAs for human granulocyte colony-stimulating factor. EMBO J 5: 575-581, 1986.

22. He RL, Zhou J, Hanson CZ, Chen J, Cheng N and Ye RD: Serum amyloid $\mathrm{A}$ induces G-CSF expression and neutrophilia via Toll-like receptor 2. Blood 113: 429-437, 2009.

23. Himes SR, Coles LS, Katsikeros R, Lang RK and Shannon MF: HTLV-1 tax activation of the GM-CSF and G-CSF promoters requires the interaction of NF-kB with other transcription factor families. Oncogene 8: 3189-3197, 1993. 
24. Nishizawa $M$ and Nagata S: Regulatory elements responsible for inducible expression of the granulocyte colony-stimulating factor gene in macrophages. Mol Cell Biol 10: 2002-2011, 1990.

25. Nagata S, Tsuchiya $M$, Asano S, Kaziro Y, Yamazaki $T$, Yamamoto O, Hirata Y, Kubota N, Oheda M, Nomura H, et al: Molecular cloning and expression of cDNA for human granulocyte colony-stimulating factor. Nature 319: 415-418, 1986.

26. Akira S, Isshiki H, Sugita T, Tanabe O, Kinoshita S, Nishio Y, Nakajima T, Hirano T and Kishimoto T: A nuclear factor for IL-6 expression (NF-IL6) is a member of a C/EBP family. EMBO J 9: 1897-1906, 1990.

27. Mitchell PJ and Tjian R: Transcriptional regulation in mammalian cells by sequence-specific DNA binding proteins. Science 245 371-378, 1989

28. Shannon MF, Coles LS, Fielke RK, Goodall GJ, Lagnado CA and Vadas MA: Three essential promoter elements mediate tumour necrosis factor and interleukin-1 activation of the granulocyte-colony stimulating factor gene. Growth Factors 7 181-193, 1992.

29. Hareng L, Meergans T, von Aulock S, Volk HD and Hartung T: Cyclic AMP increases endogenous granulocyte colony-stimulating factor formation in monocytes and THP-1 macrophages despite attenuated TNF-alpha formation. Eur J Immunol 33: 2287-2296, 2003.

30. Nishizawa $M$, Tsuchiya M, Watanabe-Fukunaga $R$ and Nagata $S$ : Multiple elements in the promoter of granulocyte colony-stimulating factor gene regulate its constitutive expression in human carcinoma cells. J Biol Chem 265: 5897-5902, 1990.

31. Asano M, Nishizawa M and Nagata S: Three individual regulatory elements of the promoter positively activate the transcription of the murine gene encoding granulocyte colony-stimulating factor. Gene 107: 241-246, 1991.

32. Brown CY, Lagnado CA and Goodall GJ: A cytokine mRNA-destabilizing element that is structurally and functionally distinct from A+U-rich elements. Proc Natl Acad Sci USA 93 13721-13725, 1996.

33. Arakawa T, Horan TP, Leong K, Prestrelski SJ, Narhi LO and $\mathrm{Hu}$ S: Structure and activity of granulocyte colony-stimulating factor derived from $\mathrm{CHO}$ cells containing cDNA coding for alternatively spliced sequences. Arch Biochem Biophys 316: 285-289, 1995.

34. Souza LM, Boone TC, Gabrilove J, Lai PH, Zsebo KM, Murdock DC, Chazin VR, Bruszewski J, Lu H, Chen KK, et al: Recombinant human granulocyte colony-stimulating factor: Effects on normal and leukemic myeloid cells. Science 232: 61-65, 1986.

35. Kubota N, Orita T, Hattori K, Oh-eda M, Ochi N and Yamazaki T: Structural characterization of natural and recombinant human granulocyte colony-stimulating factors. J Biochem 107: 486-492, 1990.

36. Hill CP, Osslund TD and Eisenberg D: The structure of granulocyte-colony-stimulating factor and its relationship to other growth factors. Proc Natl Acad Sci USA 90: 5167-5171, 1993

37. Senda T, Shimazu T, Matsuda S, Kawano G, Shimizu H, Nakamura KT and Mitsui Y: Three-dimensional crystal structure of recombinant murine interferon-beta. EMBO J 11: 3193-3201, 1992.

38. Cheers C, Haigh AM, Kelso A, Metcalf D, Stanley ER and Young AM: Production of colony-stimulating factors (CSFs) during infection: Separate determinations of macrophage-, granulocyte-, granulocyte-macrophage-, and multi-CSFs. Infect Immun 56: 247-251, 1988.

39. Vellenga E, Rambaldi A, Ernst TJ, Ostapovicz D and Griffin JD: Independent regulation of M-CSF and G-CSF gene expression in human monocytes. Blood 71: 1529-1532, 1988.

40. Jones CE and Chan K: Interleukin-17 stimulates the expression of interleukin-8, growth-related oncogene-alpha, and granulocyte-colony-stimulating factor by human airway epithelial cells. Am J Respir Cell Mol Biol 26: 748-753, 2002.

41. Sano E, Ohashi K, Sato Y, Kashiwagi M, Joguchi A and Naruse N: A possible role of autogenous IFN-beta for cytokine productions in human fibroblasts. J Cell Biochem 100: 1459-1476, 2007.

42. Jardin F, Vasse M, Debled M, Dominique S, Courville P, Callonnec F, Buchonnet G, Thiberville L and Tilly H: Intense paraneoplastic neutrophilic leukemoid reaction related to a G-CSF-secreting lung sarcoma. Am J Hematol 80: 243-245, 2005

43. Uemura Y, Kobayashi M, Nakata H, Kubota T, Saito T, Bandobashi $\mathrm{K}$ and Taguchi $\mathrm{H}$ : Role of protein kinase $\mathrm{C}$ in expression of granulocyte-colony stimulating factor and granulocyte macrophage-colony stimulating factor in lung cancer cells. Int J Mol Med 16: 873-881, 2005.
44. Tachibana M, Miyakawa A, Uchida A, Murai M, Eguchi K, Nakamura K, Kubo A and Hata JI: Granulocyte colony-stimulating factor receptor expression on human transitional cell carcinoma of the bladder. Br J Cancer 75: 1489-1496, 1997.

45. Nomura H, Imazeki I, Oheda M, Kubota N, Tamura M, Ono M, Ueyama Y and Asano S: Purification and characterization of human granulocyte colony-stimulating factor (G-CSF). EMBO J 5: 871-876, 1986

46. Chafe SC, Lou Y, Sceneay J, Vallejo M, Hamilton MJ, McDonald PC, Bennewith KL, Möller A and Dedhar S: Carbonic anhydrase IX promotes myeloid-derived suppressor cell mobilization and establishment of a metastatic niche by stimulating G-CSF production. Cancer Res 75: 996-1008, 2015.

47. Lee $\mathrm{CH}$, Lin SH, Chang SF, Chang PY, Yang ZP and Lu SC: Extracellular signal-regulated kinase 2 mediates the expression of granulocyte colony-stimulating factor in invasive cancer cells. Oncol Rep 30: 419-424, 2013.

48. Park S, Kim ES, Noh DY, Hwang KT and Moon A: H-Ras-specific upregulation of granulocyte colony-stimulating factor promotes human breast cell invasion via matrix metalloproteinase-2. Cytokine 55: 126-133, 2011.

49. Carvalho É, Hugo de Almeida V, Rondon AMR, Possik PA, Viola JPB and Monteiro RQ: Protease-activated receptor 2 (PAR2) upregulates granulocyte colony stimulating factor (G-CSF) expression in breast cancer cells. Biochem Biophys Res Commun 504: 270-276, 2018

50. Samineni S, Zhang Z and Shively JE: Carcinoembryonic antigen-related cell adhesion molecule 1 negatively regulates granulocyte colony-stimulating factor production by breast tumor-associated macrophages that mediate tumor angiogenesis. Int J Cancer 133: 394-407, 2013.

51. Welte T, Kim IS, Tian L, Gao X, Wang H, Li J, Holdman XB, Herschkowitz JI, Pond A, Xie G, et al: Oncogenic mTOR signalling recruits myeloid-derived suppressor cells to promote tumour initiation. Nat Cell Biol 18: 632-644, 2016.

52. Cosman D: The hematopoietin receptor superfamily. Cytokine 5: 95-106, 1993.

53. Touw IP and van de Geijn GJ: Granulocyte colony-stimulating factor and its receptor in normal myeloid cell development, leukemia and related blood cell disorders. Front Biosci 12: 800-815, 2007.

54. Avalos BR: Molecular analysis of the granulocyte colony-stimulating factor receptor. Blood 88: 761-777, 1996.

55. Avalos BR, Parker JM, Ware DA, Hunter MG, Sibert KA and Druker BJ: Dissociation of the Jak kinase pathway from G-CSF receptor signaling in neutrophils. Exp Hematol 25: 160-168, 1997.

56. Pencik J, Pham HT, Schmoellerl J, Javaheri T, Schlederer M, Culig Z, Merkel O, Moriggl R, Grebien F and Kenner L: JAK-STAT signaling in cancer: From cytokines to non-coding genome. Cytokine 87: 26-36, 2016.

57. Fan Z, Li Y, Zhao Q, Fan L, Tan B, Zuo J, Hua K and Ji Q: Highly expressed granulocyte colony-stimulating factor (G-CSF) and granulocyte colony-stimulating factor receptor (G-CSFR) in human gastric cancer leads to poor survival. Med Sci Monit 24: 1701-1711, 2018.

58. Dwivedi P and Greis KD: Granulocyte colony-stimulating factor receptor signaling in severe congenital neutropenia, chronic neutrophilic leukemia, and related malignancies. Exp Hematol 46: 9-20, 2017.

59. Fukui Y, Kawashima M, Kawaguchi K, Takeuchi M, Hirata M, Kataoka TR, Sakurai T, Kataoka M, Kanao S, Nakamoto Y, et al: Granulocyte-colony-stimulating factor-producing metaplastic carcinoma of the breast with significant elevation of serum interleukin-17 and vascular endothelial growth factor levels. Int Cancer Conf J 7: 107-113, 2018

60. Lawicki S, Czygier M, Omyła J and Szmitkowski M: The plasma levels of granulocyte-colony stimulating factor (G-CSF) and macrophage-colony stimulating factor (M-CSF) in breast cancer patients. Pol Arch Med Wewn 116: 749-755, 2006 (In Polish).

61. Ławicki S, Będkowska GE, Wojtukiewicz M and Szmitkowski M: Hematopoietic cytokines as tumor markers in breast malignancies. A multivariate analysis with ROC curve in breast cancer patients. Adv Med Sci 58: 207-215, 2013.

62. Bordbar E, Malekzadeh M, Ardekani MT, Doroudchi M and Ghaderi A: Serum levels of G-CSF and IL-7 in Iranian breast cancer patients. Asian Pac J Cancer Prev 13: 5307-5312, 2012.

63. Agresti R, Triulzi T, Sasso M, Ghirelli C, Aiello P, Rybinska I, Campiglio M, Sfondrini L, Tagliabue E and Bianchi F: Wound healing fluid reflects the inflammatory nature and aggressiveness of breast tumors. Cells 8: 8, 2019. 
64. Wojtukiewicz MZ, Sierko E, Skalij P, Kamińska M, Zimnoch L, Brekken RA and Thorpe PE: Granulocyte-colony stimulating factor receptor, tissue factor, and VEGF-R bound VEGF in human breast cancer in loco. Adv Clin Exp Med 25: 505-511, 2016.

65. Cao Y, Slaney CY, Bidwell BN, Parker BS, Johnstone CN, Rautela J, Eckhardt BL and Anderson RL: BMP4 inhibits breast cancer metastasis by blocking myeloid-derived suppressor cell activity. Cancer Res 74: 5091-5102, 2014.

66. Kowanetz M, Wu X, Lee J, Tan M, Hagenbeek T, Qu X, Yu L, Ross J, Korsisaari N, Cao T, et al: Granulocyte-colony stimulating factor promotes lung metastasis through mobilization of Ly6G+Ly6C+ granulocytes. Proc Natl Acad Sci USA 107: 21248-21255, 2010.

67. Guo L, Chen G, Zhang W, Zhou L, Xiao T, Di X, Wang Y, Feng L and Zhang K: A high-risk luminal A dominant breast cancer subtype with increased mobility. Breast Cancer Res Treat 175: 459-472, 2019.

68. Park J, Wysocki RW, Amoozgar Z, Maiorino L, Fein MR, Jorns J, Schott AF, Kinugasa-Katayama Y, Lee Y, Won NH, et al: Cancer cells induce metastasis-supporting neutrophil extracellular DNA traps. Sci Transl Med 8: 361ra138, 2016.

69. Demers M and Wagner DD: Neutrophil extracellular traps: A new link to cancer-associated thrombosis and potential implications for tumor progression. OncoImmunology 2: e22946, 2013.

70. Leal AC, Mizurini DM, Gomes T, Rochael NC, Saraiva EM, Dias MS, Werneck CC, Sielski MS, Vicente CP and Monteiro RQ: tumor-derived exosomes induce the formation of neutrophil extracellular traps: Implications for the establishment of cancer-associated thrombosis. Sci Rep 7: 6438, 2017.

71. Zhao CL, Zhang GP, Xiao ZZ, Ma ZK, Lei CP, Song SY, Feng YY, Zhao YC and Feng XS: Recombinant human granulocyte colony-stimulating factor promotes preinvasive and invasive estrogen receptor-positive tumor development in MMTV-erbB2 mice. J Breast Cancer 18: 126-133, 2015.

72. Waight JD, Hu Q, Miller A, Liu S and Abrams SI: Tumor-derived G-CSF facilitates neoplastic growth through a granulocytic myeloid-derived suppressor cell-dependent mechanism. PLoS One 6: e27690, 2011.

73. Espinoza-Sánchez NA, VadilloE, Balandrán JC,Monroy-García A, Pelayo R and Fuentes-Pananá EM: Evidence of lateral transmission of aggressive features between different types of breast cancer cells. Int J Oncol 51: 1482-1496, 2017.

74. Cavalloni G, Sarotto I, Pignochino Y, Gammaitoni L, Migliardi G, Sgro L, Piacibello W, Risio M, Aglietta M and Leone F: Granulocyte-colony stimulating factor upregulates ErbB2 expression on breast cancer cell lines and converts primary resistance to trastuzumab. Anticancer Drugs 19: 689-696, 2008.

75. Pondé N, Brandão M, El-Hachem G, Werbrouck E and Piccart M: Treatment of advanced HER2-positive breast cancer: 2018 and beyond. Cancer Treat Rev 67: 10-20, 2018.

76. Siegel RL, Miller KD and Jemal A: Cancer statistics, 2019. CA Cancer J Clin 69: 7-34, 2019.

77. Motz GT and Coukos G: Deciphering and reversing tumor immune suppression. Immunity 39: 61-73, 2013.

78. Almand B, Clark JI, Nikitina E, van Beynen J, English NR, Knight SC,Carbone DP and Gabrilovich DI: Increased production of immature myeloid cells in cancer patients: A mechanism of immunosuppression in cancer. J Immunol 166: 678-689, 2001.

79. Quail DF and Joyce JA: Microenvironmental regulation of tumor progression and metastasis. Nat Med 19: 1423-1437, 2013.

80. Aliper AM, Frieden-Korovkina VP, Buzdin A, Roumiantsev SA and Zhavoronkov A: A role for G-CSF and GM-CSF in nonmyeloid cancers. Cancer Med 3: 737-746, 2014.

81. Pickup MW, Owens P, Gorska AE, Chytil A, Ye F, Shi C, Weaver VM, Kalluri R, Moses HL and Novitskiy SV: Development of aggressive pancreatic ductal adenocarcinomas depends on granulocyte colony stimulating factor secretion in carcinoma cells. Cancer Immunol Res 5: 718-729, 2017.

82. Diaz-Montero CM, Salem ML, Nishimura MI, Garrett-Mayer E, Cole DJ and Montero AJ: Increased circulating myeloid-derived suppressor cells correlate with clinical cancer stage, metastatic tumor burden, and doxorubicin-cyclophosphamide chemotherapy. Cancer Immunol Immunother 58: 49-59, 2009.

83. Markowitz J, Wesolowski R, Papenfuss T, Brooks TR and Carson WE III: Myeloid-derived suppressor cells in breast cancer. Breast Cancer Res Treat 140: 13-21, 2013.

84. Sceneay J, Chow MT, Chen A, Halse HM, Wong CS, Andrews DM, Sloan EK, Parker BS, Bowtell DD, Smyth MJ, et al: Primary tumor hypoxia recruits CD11b+/Ly6Cmed/Ly6G+ immune suppressor cells and compromises NK cell cytotoxicity in the premetastatic niche. Cancer Res 72: 3906-3911, 2012.
85.Lin EY, Nguyen AV, Russell RG and Pollard JW: Colony-stimulating factor 1 promotes progression of mammary tumors to malignancy. J Exp Med 193: 727-740, 2001.

86. Aharinejad S, Paulus P, Sioud M, Hofmann M, Zins K, Schäfer R, Stanley ER and Abraham D: Colony-stimulating factor-1 blockade by antisense oligonucleotides and small interfering RNAs suppresses growth of human mammary tumor xenografts in mice. Cancer Res 64: 5378-5384, 2004.

87. Ries CH, Cannarile MA, Hoves S, Benz J, Wartha K, Runza V, Rey-Giraud F, Pradel LP, Feuerhake F, Klaman I, et al: Targeting tumor-associated macrophages with anti-CSF-1R antibody reveals a strategy for cancer therapy. Cancer Cell 25: 846-859, 2014.

88. Mantovani A and Sica A: Macrophages, innate immunity and cancer: Balance, tolerance, and diversity. Curr Opin Immunol 22: 231-237, 2010

89. Swierczak A, Cook AD, Lenzo JC, Restall CM, Doherty JP, Anderson RL and Hamilton JA: The promotion of breast cancer metastasis caused by inhibition of CSF-1R/CSF-1 signaling is blocked by targeting the G-CSF receptor. Cancer Immunol Res 2: 765-776, 2014.

90.Huang J, Simpson JF, Glackin C, Riethorf L, Wagener C and Shively JE: Expression of biliary glycoprotein (CD66a) in normal and malignant breast epithelial cells. Anticancer Res 18 (5A): 3203-3212, 1998 .

91. Meixner A, Zenz R, Schonthaler HB, Kenner L, Scheuch H, Penninger JM and Wagner EF: Epidermal JunB represses G-CSF transcription and affects haematopoiesis and bone formation. Nat Cell Biol 10: 1003-1011, 2008.

92.Kim JS, Son Y, Bae MJ, Lee M, Lee CG, Jo WS, Kim SD and Yang K: Administration of granulocyte colony-stimulating factor with radiotherapy promotes tumor growth by stimulating vascularization in tumor-bearing mice. Oncol Rep 34: 147-154, 2015.

93. Alshamrani MA, Al-Foheidi Mand Abdulrahim AH: Granulocyte Colony Stimulating Factor (G-CSF) Induced splenic infarction in breast cancer patient treated with dose-dense chemotherapy regimen. Case Rep Oncol Med 2019: 8174986, 2019.

94. Kinjo Y, Kurita T, Ueda T, Kagami S, Matsuura Y and Yoshino K: Acute arteritis after G-CSF administration. Int Cancer Conf J 8: 77-80, 2019

95. Lu X, Wu Y, Wang H and Xia L: G-CSF-induced severe thrombocytopenia in a healthy donor: A rare case report. Medicine (Baltimore) 98: e14786, 2019.

96. Kim YG, Kim SR, Hwang SH, Jung JY, Kim HA and Suh CH: Mesenteric vasculitis after G-CSF administration in a severe neutropenic patient with systemic lupus erythematosus. Lupus 25: 1381-1384, 2016.

97.Li W, Zhang X, Chen Y, Xie Y, Liu J, Feng Q, Wang Y, Yuan W and Ma J: G-CSF is a key modulator of MDSC and could be a potential therapeutic target in colitis-associated colorectal cancers. Protein Cell 7: 130-140, 2016.

98. Kumar J, Fraser FW, Riley C, Ahmed N, McCulloch DR and Ward AC: Granulocyte colony-stimulating factor receptor signalling via Janus kinase 2/signal transducer and activator of transcription 3 in ovarian cancer. Br J Cancer 110: 133-145, 2014.

99. Agarwal S, Lakoma A, Chen Z, Hicks J, Metelitsa LS, Kim ES and Shohet JM: G-CSF Promotes Neuroblastoma Tumorigenicity and Metastasis via STAT3-Dependent Cancer Stem Cell Activation. Cancer Res 75: 2566-2579, 2015.

100. Nakata H, Uemura Y, Kobayashi M, Harada R and Taguchi H: Cyclooxygenase-2 inhibitor NS-398 suppresses cell growth and constitutive production of granulocyte-colony stimulating factor and granulocyte macrophage-colony stimulating factor in lung cancer cells. Cancer Sci 94: 173-180, 2003

101. Cui YH, Suh Y, Lee HJ, Yoo KC, Uddin N, Jeong YJ, Lee JS, Hwang SG, Nam SY, Kim MJ, et al: Radiation promotes invasiveness of non-small-cell lung cancer cells through granulocyte-colony-stimulating factor. Oncogene 34: 5372-5382, 2015.

102. Ramakrishna $\mathrm{C}$ and Cantin EM: IFN $\gamma$ inhibits G-CSF induced neutrophil expansion and invasion of the CNS to prevent viral encephalitis. PLoS Pathog 14: e1006822, 2018

103. Chang SF, Li HC, Huang YP, Tasi WJ, Chou YY and Lu SC SB203580 increases G-CSF production via a stem-loop destabilizing element in the 3' untranslated region in macrophages independently of its effect on p38 MAPK activity. J Biomed Sci 23: 3, 2016.

104. Fujimoto A, Akifusa S, Hirofuji T and Yamashita Y: Involvement of suppressor of cytokine signaling-1 in globular adiponectin-induced granulocyte colony-stimulating factor in RAW 264 cell. Mol Immunol 48: 2052-2058, 2011. 
105. Kamio N, Akifusa S, Yamaguchi N and Yamashita Y: Induction of granulocyte colony-stimulating factor by globular adiponectin via the MEK-ERK pathway. Mol Cell Endocrinol 292: 20-25, 2008

106.Zhang L, Yang M, Wang Q, Liu M, Liang Q, Zhang H and Xiao X: HSF1 regulates expression of G-CSF through the binding element for NF-IL6/CCAAT enhancer binding protein beta. Mol Cell Biochem 352: 11-17, 2011.

107. Aoki Y, Hirano D, Kodama H, Nishi Y and Nakamura M: Stimulation of G-CSF gene expression in the macrophage cell line by contact with extracellular matrix proteins and a pre-B leukaemia cell line. Cytokine 10: 596-602, 1998.

108. Chou YY and Lu SC: Inhibition by rapamycin of the lipoteichoic acid-induced granulocyte-colony stimulating factor expression in mouse macrophages. Arch Biochem Biophys 508: 110-119, 2011.

109. Sallerfors B and Olofsson T: Granulocyte-macrophage colony-stimulating factor (GM-CSF) and granulocyte colony-stimulating factor (G-CSF) secretion by adherent monocytes measured by quantitative immunoassays. Eur $\mathbf{J}$ Haematol 49: 199-207, 1992.

110. Tajuddin T, Ryan EJ, Norris S, Hegarty JE and O'Farrelly C: Interferon- $\alpha$ suppressed granulocyte colony stimulating factor production is reversed by CL097, a TLR7/8 agonist. J Gastroenterol Hepatol 25: 1883-1890, 2010.

111. Ichinose Y, Hara N, Ohta M, Aso H, Chikama H, Kawasaki M, Kubota I, Shimizu T and Yagawa K: Recombinant granulocyte colony-stimulating factor and lipopolysaccharide maintain the phenotype of and superoxide anion generation by neutrophils. Infect Immun 58: 1647-1652, 1990.

112. Lindemann A, Riedel D, Oster W, Ziegler-Heitbrock HW, Mertelsmann R and Herrmann F: Granulocyte-macrophage colony-stimulating factor induces cytokine secretion by human polymorphonuclear leukocytes. J Clin Invest 83: 1308-1312, 1989.

113. Lu L, Srour EF, Warren DJ,Walker D, Graham CD, Walker EB, Jansen J, Broxmeyer HE: Enhancement of release of granulocyte- and granulocyte-macrophage colony-stimulating factors from phytohemagglutinin-stimulated sorted subsets of human $\mathrm{T}$ lymphocytes by recombinant human tumor necrosis factor-alpha. Synergism with recombinant human IFN-gamma. J Immunol 141: 201-207, 1988.

114. Lennard Richard ML, Brandon D, Lou N, Sato S, Caldwell T, Nowling TK, Gilkeson G and Zhang XK: Acetylation impacts Fli-1-driven regulation of granulocyte colony stimulating factor. Eur J Immunol 46: 2322-2332, 2016.

115. Rajavashisth TB, Andalibi A, Territo MC, Berliner JA, Navab M, Fogelman AM and Lusis AJ: Induction of endothelial cell expression of granulocyte and macrophage colony-stimulating factors by modified low-density lipoproteins. Nature 344: 254-257, 1990.

116. Seelentag WK, Mermod JJ, Montesano R and Vassalli P: Additive effects of interleukin 1 and tumour necrosis factor-alpha on the accumulation of the three granulocyte and macrophage colony-stimulating factor mRNAs in human endothelial cells. EMBO J 6: 2261-2265, 1987.

117. Saba S, Soong G, Greenberg S and Prince A: Bacterial stimulation of epithelial G-CSF and GM-CSF expression promotes PMN survival in CF airways. Am J Respir Cell Mol Biol 27: 561-567, 2002.

118. Suzukawa M, Koketsu R, Baba S, Igarashi S, Nagase H, Yamaguchi M, Matsutani N, Kawamura M, Shoji S, Hebisawa A, et al: Leptin enhances ICAM-1 expression, induces migration and cytokine synthesis, and prolongs survival of human airway epithelial cells. Am J Physiol Lung Cell Mol Physiol 309: L801-L811, 2015

119. Numasaki M, Takahashi $H$, Tomioka $Y$ and Sasaki $H$ Regulatory roles of IL-17 and IL-17F in G-CSF production by lung microvascular endothelial cells stimulated with IL-1beta and/or TNF-alpha. Immunol Lett 95: 97-104, 2004.

120. Witowski J, Ksiazek K, Warnecke C, Kuźlan M, Korybalska K, Tayama H, Wiśniewska-Elnur J, Pawlaczyk K, Trómińska J, Breborowicz A, et al: Role of mesothelial cell-derived granulocyte colony-stimulating factor in interleukin-17-induced neutrophil accumulation in the peritoneum. Kidney Int 71: 514-525, 2007.

121.Demetri GD, Zenzie BW, Rheinwald JG and Griffin JD Expression of colony-stimulating factor genes by normal human mesothelial cells and human malignant mesothelioma cells lines in vitro. Blood 74: 940-946, 1989.

122. Carr MJ, Li Y, Rezakhanlou AM and Ghahary A Keratinocyte-releasable factors stimulate the expression of granulocyte colony-stimulating factor in human dermal fibroblasts. J Cell Biochem 118: 308-317, 2017.
123. Ramachandran R, Morice AH and Compton SJ: Proteinase-activated receptor 2 agonists upregulate granulocyte colony-stimulating factor, IL-8, and VCAM-1 expression in human bronchial fibroblasts. Am J Respir Cell Mol Biol 35: $133-141,2006$.

124.Koeffler HP, Gasson J, Ranyard J, Souza L, Shepard M and Munker R: Recombinant human TNF alpha stimulates production of granulocyte colony-stimulating factor. Blood 70: $55-59,1987$

125. Seelentag W, Mermod JJ and Vassalli P: Interleukin 1 and tumor necrosis factor-alpha additively increase the levels of granulocyte-macrophage and granulocyte colony-stimulating factor (CSF) mRNA in human fibroblasts. Eur J Immunol 19: 209-212, 1989.

126.Zgheib A, Lamy S and Annabi B: Epigallocatechin gallate targeting of membrane type 1 matrix metalloproteinase-mediated Src and Janus kinase/signal transducers and activators of transcription 3 signaling inhibits transcription of colony-stimulating factors 2 and 3 in mesenchymal stromal cells. J Biol Chem 288: 13378-13386, 2013

127. Fibbe WE, van Damme J, Billiau A, Goselink HM, Voogt PJ, van Eeden G, Ralph P, Altrock BW and Falkenburg JH: Interleukin 1 induces human marrow stromal cells in long-term culture to produce granulocyte colony-stimulating factor and macrophage colony-stimulating factor. Blood 71: 430-435, 1988

128. Tesio M, Oser GM, Baccelli I, Blanco-Bose W, Wu H, Göthert JR, Kogan SC and Trumpp A: Pten loss in the bone marrow leads to G-CSF-mediated HSC mobilization. J Exp Med 210: 2337-2349, 2013.

129. Grace MB, Singh VK, Rhee JG, Jackson WE III, Kao TC and Whitnall MH: 5-AED enhances survival of irradiated mice in a G-CSF-dependent manner, stimulates innate immune cell function, reduces radiation-induced DNA damage and induces genes that modulate cell cycle progression and apoptosis. J Radiat Res (Tokyo) 53: 840-853, 2012.

130.Kimura A, Kinjyo I, Matsumura Y, Mori H, Mashima R, Harada M, Chien KR, Yasukawa $\mathrm{H}$ and Yoshimura A: SOCS3 is a physiological negative regulator for granulopoiesis and granulocyte colony-stimulating factor receptor signaling. J Biol Chem 279: 6905-6910, 2004.

131. Smith A, Witte E, McGee D, Knott J, Narang K and Racicot K: Cortisol inhibits CSF2 and CSF3 via DNA methylation and inhibits invasion in first-trimester trophoblast cells. Am J Reprod Immunol 78: e12741, 2017.

132. Ordelheide AM, Gommer N, Böhm A, Hermann C, Thielker I, Machicao F, Fritsche A, Stefan N, Häring HU and Staiger H: Granulocyte colony-stimulating factor (G-CSF): A saturated fatty acid-induced myokine with insulin-desensitizing properties in humans. Mol Metab 5: 305-316, 2016

133. Hudock KM, Liu Y, Mei J, Marino RC, Hale JE, Dai N and Worthen GS: Delayed resolution of lung inflammation in Il-1 rn-/mice reflects elevated IL-17A/granulocyte colony-stimulating factor expression. Am J Respir Cell Mol Biol 47: 436-444, 2012.

134. Soria-Castro I, Krzyzanowska A, Pelaéz ML, Regadera J, Ferrer G, Montoliu L, Rodríguez-Ramos R, Fernández M and Alemany S: Cot/tp12 (MAP3K8) mediates myeloperoxidase activity and hypernociception following peripheral inflammation. J Biol Chem 285: 33805-33815, 2010.

135.Janelle MF, Doucet A, Bouchard D, Bourbonnais Y and Tremblay GM: Increased local levels of granulocyte colony-stimulating factor are associated with the beneficial effect of pre-elafin (SKALP/trappin-2/WAP3) in experimental emphysema. Biol Chem 387: 903-909, 2006.

136. Bohannon JK, Luan L, Hernandez A, Afzal A, Guo Y, Patil NK, Fensterheim B and Sherwood ER: Role of G-CSF in monophosphoryl lipid A-mediated augmentation of neutrophil functions after burn injury. J Leukoc Biol 99: 629-640, 2016.

137. Ellis GS, Carlson DE, Hester L, He JR, Bagby GJ, Singh IS and Hasday JD: G-CSF, but not corticosterone, mediates circulating neutrophilia induced by febrile-range hyperthermia. J Appl Physiol 98: 1799-1804, 2005.

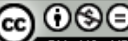

This work is licensed under a Creative Commons Attribution-NonCommercial-NoDerivatives 4.0 International (CC BY-NC-ND 4.0) License. 